\title{
Personlige opplevelser
}

\section{Soga om ein cyste}

Eg fekk ein cyste på ein finger. Det beste ville vere å få han fjerna. Det skulle ta meg to år og 11 overlegar å få det gjort. Kva dette har kosta helsevesenet, vågar eg ikkje tenkje på. Historia er eit døme på ineffektivitet $\mathrm{i}$ eit overadministrert helsevesen. Kan det vere ei av årsakene til «legemangelen»?

Det starta som ein raud papel radialt for ekstensorsena over distale interfalangealledd på tredje høgre finger. Denne utvikla seg til ein typisk mukoid epidermalcyste, som var i vegen heile tida.

På ei kullsamling konsulterte eg tre andre kirurgiske overlegar, som alle var samde i diagnosen og $i$ at cysten burde fjernast før han vart så stor at det vart vanskar med huddekning. Men:

Ortopedisk kirurg 1 dreiv ikkje med slik kirurgi (men skulle eg trenge hofteoperasjon, kunne det bli ei råd).

Ortopedisk kirurg 2 dreiv heller ikkje med slik kirurgi (men skulle eg trenge ryggoperasjon, kunne det bli ei råd).

Generell kirurg (ja, det fanst faktisk slike i 2006) hadde gjort slike inngrep, men var no, som eg, pensjonist og hadde ikkje tilgang på høveleg verkty.

For å finne ein handkirurg lokalt kontakta eg ein overlege (kardiolog) eg kjenner og fekk oppgitt ein revmakirurg. Kardiologen var òg samd i diagnosen, som då var verifisert av fem overlegar (inklusive meg sjølv).

Etter ei viss ventetid fekk eg time hos revmakirurgen, men eg skulle fyrst møte på røntgen for å ta bilete av båe hendene. Det tykte eg var uturvande sløsing med ioniserande strålar og ressursar og ringde for å snakke med legen. Han var ikkje å treffe. For ikkje å måtte utsetje behandlinga ytterlegare «slukte eg kamelen» og fekk teke røntgenbileta. Også denne sjette overlegen i cystesoga var samd i diagnosen, men behandlinga innskrenka seg til punksjon og aspirasjon. Einaste grunnen eg kan tenkje meg til at denne nyttelause prosedyren vart gjort, måtte vere at det utløyste ein takst.

\section{Eit år går}

Så var eg vekkreist eit år. Cysten gjekk inn i ein syklus med vekst, perforasjon og ny vekst. Med ein slik lokalisasjon vart han stadig traumatisert, så om ein kallar perforasjonane spontane eller traumatiske kan vel vere hipp som happ. Ein gong vart han infisert, så eg måtte fram med lommekniven og insidere for å tømme ut pusset og applisere jodsprit.

På ei reise fekk eg hjelp av ein anestesioverlege (sjuande overlegen i cystesoga) eg kjenner til å snike meg til ein korridorkonsultasjon hos ein handkirurg. Han var den åttande overlegen som verifiserte diagnosen, og han tilbaud seg å fjerne cysten kirurgisk. Men sidan det var ventetid og eg berre var på gjennomreise, valde eg å søkje om time til behandling på ein plastikkirurgisk poliklinikk nærare heimen. Sødnaden var vedlagt fargefoto av cysten i to plan (fig 1).

Då eg etter over seks veker ikkje hadde høyrt noko, ringde eg og fekk vite at dei hadde fått søknaden. Sidan eg ikkje etter ytterlegare eit par veker hadde høyrt meir, søkte eg òg om behandlingstime hos den ovanfornemnde handkirurgen ein annan stad i landet. Etter to månader kom der så til overmål to skriv frå plastikkirurgisk poliklinikk, vedlagt eit tosidig skriv om pasientrett til undersøking/behandling innan fire månader, med frist fastsett til ein viss dato. Men denne fristen greidde dei ikkje halde. Då eg endeleg fekk varsel om time, var det presisert at det var til undersøking, ikkje behandling.

Sidan cysten alt var undersøkt av åtte overlegar, meinte eg det var uturvande å kaste vekk ein heil dag i reising og leggje ut ytterlegare om lag 1500 kroner for at ein niande overlege skulle stille diagnosen. Eg ringde derfor overlegen, som gjekk med på å setje meg opp direkte til operasjon og eventuelt stryke meg av programmet om han ikkje fann det indisert. Dermed vart det ytterlegare ventetid. I mellomtida utveksla eg tankar om kirurgisk teknikk per brev med plastikkirurgen.

\section{Operasjon}

Som ved eit skjebnens lune fekk eg omsider time same dato både frå ovanfornemnde handkirurg og frå plastikkirurgisk poliklinikk. Då valde eg den som låg nærast. Der vart alt gjort etter alle «kunstens» reglar: Inn på operasjonsstove, opp på operasjonsrettar. Det gjekk fram at eg hadde juridisk bord, armen på sidebord, tildekking med grønt, plastikkirurgen (den niande overlegen som ved sjølvsyn kunne verifisere diagnosen) og operasjonssjukepleiaren vaska og kledde seg sterilt, fingeren vart regionalanestesert ved basis (Xylocain med adrenalin!), ein sjukepleiar gjekk «laus», armen vart spritvaska til albogen. Korleis inngrepet vart utført, veit eg ikkje, for andletet mitt var løynt bak grønt klede. Eg spurde om cysten kommuniserte med leddet, men fekk ikkje noko definitivt svar.

Eg fekk tilsendt histologisvaret, som ikkje minte om ganglion.

\section{Residiv og kryoterapi}

Etter kort tid residiverte cysten, noko eg gjorde kirurgen merksam på skriftleg - på dagen to år etter at eg hadde konsultert dei fyrste overlegane.

Ein månad seinare var eg på ein dermatologisk poliklinikk for noko heilt anna, men spurde i forbifarten dermatologioverlegen (den tiande overlegen i cystesoga) om dei behandla mukoide epidermalcyster. Han tilkalla ein dermatologioverlegekollega

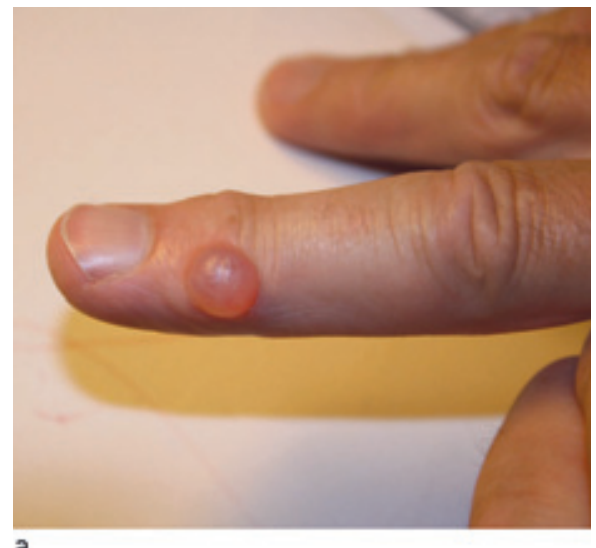

a

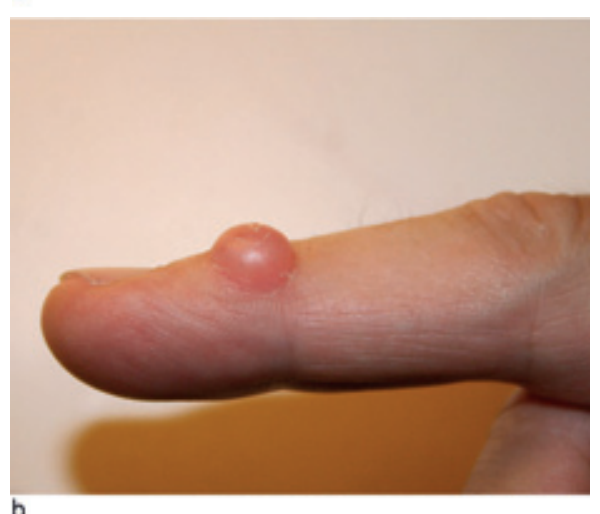

Figur 1 a, b) Cysten kort før kryoterapi 


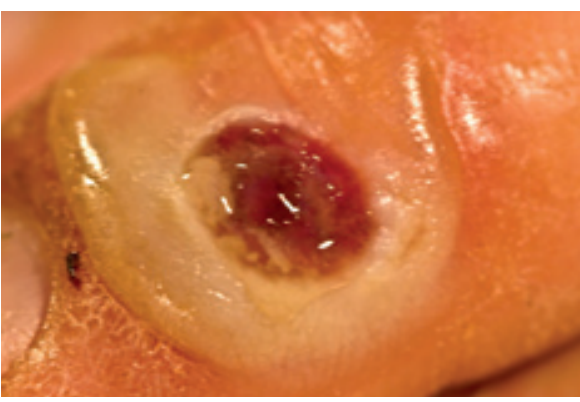

Figur 2 Kryoprosedyren etterlet eit krater

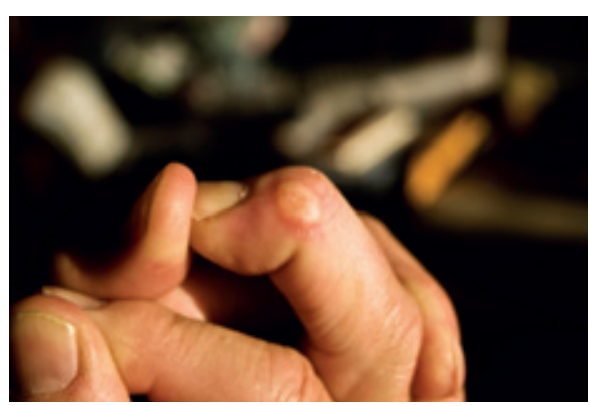

Figur 3 Kort etter epitaliseringa residiverte cysten

(nr. 11!). Då skjedde ting fort: Eg sat på ein stol med fingeren ut $i$ vêret, og resolutt vart cyste med omgivingar frosen ned med flytande nitrogen og cysten sneia vekk med skalpell i nivå med hudoverflata. Deretter vart området på nytt frose ned. Her var tydelegvis sterilitet/aseptikk eit ikkje-tema. Kontrasten til prosedyren ved plastikkirurgisk poliklinikk kunne ikkje ha vore større. Det vart lagt på ein bandasje, og eg fekk instruks om å bruke Brulidine-krem på såret.

Kryoprosedyren etterlet eit relativt stort nekrotisk krater (fig 2), og ein lymfeknute i aksillen vart svært øm. Den roa seg då eg gjekk over frå Brulidine til Fucidin-salve på såret.

Tre og ein halv månad etter at eg rapporterte til plastikkirurgen om residivet, fekk eg varsel om ny time. Men slik fingeren såg ut då, låg tilhøva ikkje til rette for meir kirurgi.

Fyrst etter 13 veker var området reepitelialisert etter kryokirurgien. Hadde dette vore i min yrkesaktive periode, hadde eg vore utelukka frå all kirurgisk aktivitet i over tre månader, noko som hadde fått ringverknader på arbeidsplassen. Kort tid etter epitelialiseringa residiverte cysten, med breiare basis enn før (fig 3).

\section{Avslutning}

Dette har kosta meg ikkje lite tid og pengar. Kva det har kosta helsevesenet, vågar eg ikkje tenkje på eingong. Dette må vere eit strålande døme på ineffektivitet $i$ eit overadministrert helsevesen. Kan det vere ei av årsakene til den såkalla legemangelen?
Sidan det såg ut som om norske helsevesenet hadde tømt sitt terapeutiske armamentarium, vurderte eg å reise ein stad der dei hadde røynsle med «tradisjonell medisin» og prøve med flaggermusblod eller noko slikt. Resultatet kunne neppe blitt dårlegare og ulempene neppe større.

Men så vart fingeren uforvarande utsett for eit traume så cysteinnhaldet vart hemoragisk - og cysten tok til å minke. Det førde tanken inn på ei behandling eg i si tid las om i mi nordiske «lærebog» i kirurgi (frå 1957): »...sprängning av cystan genom att hårt pressa den mot underlaget.»

Før i tida var det noko som heitte chirurgia minor, som distriktslegen ordna på kontoret. Ventetida var færre timar på venterommet enn månader $i$ dagens helsevesen. Men distriktslegen er som kjent ein utrydda rase.

I nemnde «lærebog» står det diverre: «Detta leder dog ofte til recidiv.» Så kanskje eg til slutt må prøve noko «alternativt» likevel?

\section{Otto Inge Molvær \\ marinmed@frisurf.no \\ 5555 Førde i Hordaland}

Manuskriptet ble mottatt 27.3. 2009 og godkjent

11.6. 2009. Medisinsk redaktør Erlend Hem.

\section{Vurdering og behandling av tumor på hånd}

Årsakene til tumor på hånden kan være mange, og det er derfor viktig at de som vurderer dette, innehar tilfredsstillende kompetanse slik at det blir håndtert riktig. Otto Inge Molværs sykehistorie er et godt eksempel på en medisinsk problemstilling som ikke er blitt tilfredsstillende vurdert og behandlet. Som han angir har dette medvirket til lang behandlingstid innen flere spesialiteter med en betydelig økonomisk kostnad både for pasient og helsevesen.

\section{Diagnostikk}

Ved vurdering av tumor på hånden må man i første omgang skille mellom godartede og ondartede forandringer. Dette er avgjørende i forhold til hastegrad for behandling og for hvilken prosedyre som skal benyttes. De godartede tumorene kan videre kategoriseres i cystiske og solide svulster. Er man usikker på diagnosen, bør den verifiseres med (eksisjons-) biopsi, alternativt kan det rekvireres MR- eller ultralydundersøkelse. Basert på Molværs sykehistorie med utvik- ling av en cystisk tumor og ut fra vedlagte bilder vil følgende differensialdiagnoser være aktuelle (1):

Synovialt ganglion. Dette er den hyppigst forekommede tumor på hånden, hvor leddvæske presses gjennom synovialmembranen og hvor det foreligger en ventilmekanisme som gjør at væsken ikke returneres. Mukoid cyste er en form for ganglion, men er assosiert med degenerativ leddsykdom. Den økte leddvæskeproduksjonen gir da utbuking av leddkapselen på det svakeste punktet, ofte ved proksimale neglevoll. Dette kan igjen føre til dystrofi av neglen. De mukoide cystene har også lettere for å rupturere spontant. Sannsynligvis er dette den riktige diagnosen hos Molvær. I dette tilfellet vil det derfor være mest korrekt å undersøke med røntgen for vurdering av degenerative forandringer som eventuelt bør behandles.

Epidermoid cyste (inklusjonscyste). Disse tumorene utvikles langsomt, oftest på palmarsiden, hvor spontan eller traumatisk betinget okklusjon av epidermale celler som produserer keratin eller andre epidermale produkter fører til en cystisk hevelse.

Andre godartede svulster på hånden. Det kan være kjempecellesvulst på seneskjeden (ofte traumatisk betinget og en relativt vanlig solid svulst), (dermato-) fibromer (ofte nodulære og faste svulster i hud), fremmedlegemereaksjoner/granulomer, pyogent granulom, nevrofibrom, Heberdens knuter ved artrose, vorter (verucca vulgaris), aktinsk keratose (kun mens forandringen var i tidlig fase, da dette er relativt flate lesjoner).

Ondartede svulster. Dette kan være plateepitelcellekreft, keratoakantom (potensiell malignitetsfare), basalcellekreft, amelanotisk melanom.

På bakgrunn av tumorens farge i dette tilfellet vil pigmenterte lesjoner som for eksempel malignt melanom og vaskulære lesjoner være mindre aktuelle.

\section{Behandling}

De ulike diagnosene innebærer forskjellig type behandling, og legen som behandler 